\title{
The effect of sonication and heat treatment on the physicochemical, nutritional and microbiological properties of different sugarcane variants
}

\author{
Nazariah JASMI ${ }^{1}$, Nusrah MANSOR ${ }^{1}$, Elicia Jitming LIM$^{2}$, Noor Liyana YUSOF${ }^{1}$, Siti HAJAR-AZHARI ${ }^{1}$, \\ Muhamad Hafiz Abd RAHIM ${ }^{1 *}$ (iD
}

\begin{abstract}
Red sugarcane (RS) is a lesser bred of sugarcane variant in Malaysia compared to yellow sugarcane (YS), thus less data is available regarding this species. In this study, the physicochemical and microbiological properties of RS was determined and compared with YS under different conditions. Both sugarcane variants were subjected to heat and sonication treatments for 5 and 15 minutes as a method for preservation. RS contains a higher ${ }^{\circ}$ Brix (15) compared to YS (14), and was unchanged while YS demonstrated a significant reduction. Furthermore, RS displayed a superior fructose $(+802 \%)$, glucose $(+119 \%)$ and sucrose $(+17.91 \%)$ levels in all samples and they were largely preserved during both treatments. However, RS was sensitive to colour changes, as darker juice (decrease in lightness and increase in redness) was produced after treatments. RS possessed lower phenolic content (-31.15\%) and antioxidant activity (-11.51\%) than YS, and was significantly affected by both treatments. Sonication was more effective in reducing the microbial content than heat in both treatments. These findings indicated that RS is better at retaining its physicochemical properties under preservation treatment, but less resistant in preserving its appearance and nutritional values.
\end{abstract}

Keywords: sugarcane; heat; sonication; physicochemical; nutritional; microbial.

Practical Application: These findings indicated that RS could be commercialised due to its physicochemical resistance towards preservation treatments, although it also possesses lower nutritional values than YS.

\section{Introduction}

Sugarcane (Saccharum officinarum) is a tall perennial true grass grown in many warm and temperate regions, especially in certain tropical and subtropical countries. It is often employed in the food industry specifically for the extraction of sugar and also for the production of sugarcane juice (Solomon \& Li, 2016). Sugarcane is normally classified based on skin colour, although the juice does not necessarily display the same colour as the skin. Sugarcane is rich in nutrients which provide a wide range biological effects, such as energy boosters, immunostimulants (El-Abasy et al., 2002), antioxidant and protection against radiation induced DNA damage (Kadam et al., 2008).

Due to the presence of high water activity and sugar, sugarcane juice tends to deteriorate rapidly. Therefore, to preserve its quality, the sugarcane juice is often subjected to heat treatment. However, this method has been known to cause nutritional degradation and undesirable changes in the natural sensory characteristics of sugarcane juice (Chauhan et al., 2002). Non-thermal treatments such as ultrasound treatment have been actively explored in recent years, as it involves minimal processing (Abbasi et al., 2019; Balthazar et al., 2019; Bhavya \& Hebbar, 2019; Guimarães et al., 2019b; Mohd Khairi et al., 2018; Soltani et al., 2018). Minimal processing would significantly help to retain several nutritional and antioxidant properties of the product (Fernández-Barbero et al., 2019; Guimarães et al., 2019a; Guimarães et al., 2019b). This method may reduce the microbiological presence by manipulating the pressure changes, resulting in high shearing effects and high localized temperature (Guimarães et al., 2019a; Piyasena et al., 2003). Thus, ultrasound treatment may be an effective alternative to thermal treatments on sugarcane juice.

This study aims to characterise the nutritional, physicochemical and microbiological properties of a lesser known variety of red sugarcane (Ragnar) against the commercial yellow sugarcane (Tebu Telor), before and after the preservation treatments. The preservation treatments will involve the use of heat at $90^{\circ} \mathrm{C}$ ( 5 and 15 minutes) and sonication in a waterbath at $40^{\circ} \mathrm{C}$ (5 and 15 minutes). Based on previous studies, $40^{\circ} \mathrm{C}$ is an optimal temperature for sonication (Hajar et al., 2018).

\section{Material and methods}

\subsection{Sample}

The samples of red sugarcane (RS) and yellow sugarcane (YS) were obtained from a sugarcane farm in Pendang, Kedah, Malaysia, after 6-months cultivation. They were freshly harvested using a three-roller power crusher and filtered using 6-layered muslin cloth. The sugarcane juice samples were stored in sterilized falcon tubes at $-20^{\circ} \mathrm{C}$. 


\subsection{Juice treatment}

For heat treatment, the sugarcane juice samples heated at $90{ }^{\circ} \mathrm{C}$ for 5 minutes and 15 minutes and cooled before being stored in a freezer at $-18{ }^{\circ} \mathrm{C}$. For sonication treatment, both red and yellow sugarcane juice samples were subjected to ultrasound for 30 minutes in a $40{ }^{\circ} \mathrm{C}$ and $60{ }^{\circ} \mathrm{C}$ water bath. The juice was then cooled down before stored in freezer at $-18^{\circ} \mathrm{C}$ until analysis.

\subsection{Determination of physicochemical properties}

The moisture and ash content were determined using AOAC (Horwitz \& Latimer, 2005), a type of oven drying method. Crude protein was determined using the Micro Kjeldahl method (Horwitz \& Latimer, 2005) which consists of digestion, neutralization and titration steps. Crude fibre was determined using dry ash method (Horwitz \& Latimer, 2005). Total soluble solid was measured using a hand refractometer (Model N1, ATAGO CO., LTD, USA, Brix 0-32\%) and expressed in terms of Brix degrees ( ${ }^{\circ}$ Brix) using the method described previously (Ranganna, 1979). The $\mathrm{pH}$ of the sample was determined using a $\mathrm{pH}$ electrode attached to a pH meter (Mettler Toledo, Schwerzenbach, Switzerland). Prior to use, the $\mathrm{pH}$ meter was calibrated using buffer solutions of $\mathrm{pH} 4.01,7.00$, and 9.21. Titratable acidity was measured using titration method, utilising the $\mathrm{NaOH}$ solution (Ranganna, 1979). All colour analysis was performed using the Hunterlab Calorimeter Ultra-Scan, Model SN 7877. Triplicate values were taken and expressed as CIELAB $\left(\mathrm{L}^{*} \mathrm{a}^{*} \mathrm{~b}^{*}\right.$ colour space) where $\mathrm{L}^{\star}$ - Lightness $(0=$ black, $100=$ white $), \mathrm{a}^{\star}\left(-\mathrm{a}^{\star}=\right.$ green, $+\mathrm{a}^{\star}=$ red $)$, and $b^{\star}\left(-b^{\star}=\right.$ blue, $+b^{\star}=$ yellow $)$. Rheological measurements were carried out using Rheometer RheolabQC manufactured by Anton Paar, USA, with cone and plate geometry $(60 \mathrm{~mm}$ disc, $1^{\circ}$ angle) under controlled temperature of $25^{\circ} \mathrm{C}$.

\subsection{Determination of nutritional qualities}

The glucose, fructose and sucrose content of the sugar cane juice were determined using High Performance Liquid Chromatography (HPLC) with Waters 410 Differential Refractive Index Detector. For the mobile phase, acetonitrile was mixed with water in a ratio of (80:20). The glucose, fructose and sucrose stock solutions were prepared by mixing $2.5 \mathrm{~g}$ of each and dissolving it with $100 \mathrm{~mL}$ distilled water in a $100 \mathrm{~mL}$ volumetric flask to obtain a $2.5 \%$ stock solution. $2.0,1.5,1.0$ and $0.5 \%$ of the standard solution were obtained by serial dilution of the $2.5 \%$ stock solution. Samples were diluted once in 1:1 ratio with distilled water. $20 \mu \mathrm{L}$ of glucose, fructose and sucrose single solutions were separately injected into the injection pot, followed by different concentrations of standard solution and samples with a flow rate of $1.0 \mathrm{~mL} / \mathrm{min}$, using $\mathrm{NH}_{2}(5 \mu \mathrm{m})$ column.

The total phenolic contents (TPC) of the sugarcane juice were measured using a modified Folin-Ciocalteu method (Nurul et al., 2012). $20 \mu \mathrm{L}$ of different concentrations of the standard gallic acid solution and diluted samples were added to the 96 well microplate followed by an additional $100 \mu \mathrm{L}$ of $10 \%$ Folin-Ciocalteu reagent and $80 \mu \mathrm{L}$ of $0.75 \%$ sodium carbonate solution. The microplate was covered with aluminum foil and incubated in dark conditions at room temperature for 30 minutes. The absorbance was read using BIO-RAD 170-6930 Benchmark
Plus Microplate Spectrophotometer at $760 \mathrm{~nm}$ wavelength and the results were obtained by the Microplate Manager Software. TPC of samples were expressed in milligrams of gallic acid equivalents per $\mathrm{mL}$ of sugar cane juice using the regression equation: $\mathrm{y}=0.0128 \mathrm{x}-0.2106$.

The free radical scavenging properties of the sugarcane juices were determined using standard DPPH (1,1-diphenyl2-picrylhydrazyl) method with modifications. $100 \mu \mathrm{L}$ of five-fold diluted sample were injected into the 96 well microplate followed by an additional $50 \mu \mathrm{L}$ of DPPH reagent using micropipette and then mixed well. The microplate was covered with aluminum foil and incubated in dark conditions at room temperature for 30 minutes. The absorbance was read using BIO-RAD 170-6930 Benchmark Plus Microplate Spectrophotometer at $517 \mathrm{~nm}$ wavelength and the results were obtained using the Microplate Manager Software. The free radical scavenging activity was calculated by comparing the absorbance of each sample with that of the blank containing only DPPH reagent and the solvent (distilled water).

\subsection{Total Plate Count (TPC)}

$1 \mathrm{~mL}$ of sugarcane juice was transferred into a universal bottle containing $9 \mathrm{~mL}$ of $0.1 \%$ buffered peptone water $\left(10^{-1}\right.$ dilution $)$. The mixture was homogenized and diluted up to $10^{-4}$. Next, $0.1 \mathrm{~mL}$ from $10^{-3}$ and $10^{-4}$ dilution were spread on Tryptone glucose yeast agar (Oxoid Ltd., Basingstoke, Hampshire, England) for a viable count. The plates were allowed to sit at room temperature until the liquid soaked into the agar and then placed in an incubator at $35^{\circ} \mathrm{C}$ for 48 hours. The total count of bacteria, yeast and mould will be expressed as colony forming unit (CFU) per millilitre.

\subsection{Statistical analysis}

Data were presented as mean \pm standard error of mean (SEM). Statistical analysis was conducted using Minitab 16 (Minitab Inc. State College, Pa. U.S.A). One-way analysis of variance (ANOVA) with Tukey's test was used to test for significant differences among levels of treatment. Independent-Samples T-Test was used to test for significant differences between the two samples and the significant values were considered at the level of $\mathrm{p}<0.05$.

\section{Result and discussion}

\subsection{Effect of heat and sonication treatment on the physicochemical and nutritional properties of different sugarcane variants}

Moisture content is inversely proportional to the amount of dry matter in the food. The effect of heat treatment and sonication on moisture content, total soluble solid ( $\left.{ }^{\circ} \mathrm{Brix}\right), \mathrm{pH}$, titratable acidity (TA) and viscosity of sugarcane juices are shown in Table 1. (RS) exhibited significantly lower moisture content $(\mathrm{P}<0.05)$ compared to (YS) for both treated and untreated samples. This can be explained due to the higher presence of total soluble solids, TSS (measured in the form of ${ }^{\circ}$ Brix) in sugarcane, which reduced the amount of moisture available in 
Table 1. Effects of heat treatment and sonication on physico-chemical properties of the different sugarcane juice variants.

\begin{tabular}{|c|c|c|c|c|c|c|c|c|}
\hline Treatment & Sample & $\mathrm{t}(\min )$ & $\mathrm{T}\left({ }^{\circ} \mathrm{C}\right)$ & Moisture (\%) & TSS ( ${ }^{\circ}$ Brix $)$ & $\mathrm{pH}$ & TA (\%) & $\mathrm{H} \times 10^{-3}$ (Pa.s) \\
\hline Untreated & YS & - & - & $93.50 \pm 0.02^{\mathrm{aA}}$ & $14.00 \pm 0.00^{\mathrm{aA}}$ & $6.07 \pm 0.02^{\mathrm{aA}}$ & $0.03 \pm 0.01^{\mathrm{aA}}$ & $0.50 \pm 0.02^{\mathrm{aA}}$ \\
\hline \multirow[t]{2}{*}{ Heat } & & 5 & 90 & $93.31 \pm 0.06^{\mathrm{bA}}$ & $12.80 \pm 0.30^{\mathrm{aB}}$ & $5.92 \pm 0.01^{\mathrm{aB}}$ & $0.08 \pm 0.00^{\mathrm{aB}}$ & $0.48 \pm 0.00^{\mathrm{aB}}$ \\
\hline & & 15 & 90 & $93.14 \pm 0.05^{\mathrm{bA}}$ & $12.30 \pm 0.60^{\mathrm{aB}}$ & $5.89 \pm 0.01^{\mathrm{aB}}$ & $0.07 \pm 0.00^{\mathrm{aB}}$ & $0.58 \pm 0.16^{\mathrm{aAI}}$ \\
\hline \multirow[t]{2}{*}{ Sonication } & & 5 & 40 & $92.93 \pm 0.05^{\mathrm{bA}}$ & $12.50 \pm 0.50^{\mathrm{aB}}$ & $5.92 \pm 0.01^{\mathrm{aB}}$ & $0.16 \pm 0.00^{\mathrm{aC}}$ & $0.48 \pm 0.00^{\mathrm{aB}}$ \\
\hline & & 15 & 40 & $92.85 \pm 0.07^{\mathrm{bA}}$ & $13.20 \pm 0.20^{\mathrm{aB}}$ & $5.89 \pm 0.02^{\mathrm{aB}}$ & $0.14 \pm 0.01^{\mathrm{aC}}$ & $0.48 \pm 0.00^{\mathrm{aB}}$ \\
\hline Untreated & RS & - & - & $90.97 \pm 0.01^{\mathrm{cA}}$ & $15.00 \pm 0.00^{\mathrm{bC}}$ & $5.74 \pm 0.04^{\mathrm{bC}}$ & $0.15 \pm 0.01^{\mathrm{bD}}$ & $1.10 \pm 0.14^{\mathrm{bC}}$ \\
\hline \multirow[t]{2}{*}{ Heat } & & 5 & 90 & $91.10 \pm 0.03^{\mathrm{cA}}$ & $16.00 \pm 0.00^{\mathrm{bC}}$ & $5.68 \pm 0.05^{\mathrm{bD}}$ & $0.30 \pm 0.01^{\mathrm{bE}}$ & $1.09 \pm 0.01^{\mathrm{bC}}$ \\
\hline & & 15 & 90 & $90.89 \pm 0.06^{\mathrm{cA}}$ & $16.00 \pm 0.00^{\mathrm{bC}}$ & $5.63 \pm 0.01^{\mathrm{bD}}$ & $0.26 \pm 0.0^{\mathrm{bE}}$ & $1.03 \pm 0.08^{\mathrm{bC}}$ \\
\hline \multirow[t]{2}{*}{ Sonication } & & 5 & 40 & $91.36 \pm 0.06^{\mathrm{cA}}$ & $17.70 \pm 0.60^{\mathrm{bC}}$ & $5.65 \pm 0.01^{\mathrm{bD}}$ & $0.35 \pm 0.03^{\mathrm{bF}}$ & $1.09 \pm 0.33^{\mathrm{bC}}$ \\
\hline & & 15 & 40 & $91.14 \pm 0.07^{\mathrm{cA}}$ & $16.30 \pm 0.60^{\mathrm{bC}}$ & $5.66 \pm 0.01^{\mathrm{bD}}$ & $0.33 \pm 0.02^{\mathrm{bF}}$ & $1.06 \pm 0.16^{\mathrm{bC}}$ \\
\hline
\end{tabular}

Data given as mean \pm standard deviation where $(n=3)$. Values with a small letter represent significant differences between sugarcane variants while a capital letter represent significant difference between sugarcane sample and treatment in the particular column. $\mathrm{t}=$ time, $\mathrm{T}=$ temperature, $\mathrm{TSS}=$ total soluble solid, $\mathrm{TA}=$ titratable acidity.

the juice (Krishnakumar, 2012). Due to lower moisture content and higher TSS, the viscosity of RS is significantly higher than YS.

The heat treatment caused evaporation of moisture from YS, therefore reducing its moisture content, as also observed in other fruit juices (Gizachew et al., 2016; Tandon et al., 2003). In addition, all treatments caused the reduction in ${ }^{\circ}$ Brix and viscosity of YS (but not RS), which was likely caused by the conversion of sugar to acid (Khare et al., 2012). This is in agreement with Juszczak et al. (2010), which demonstrated that dynamic viscosity of beetroot juice concentrate is dependent on its soluble solid content (Juszczak et al., 2010). However, no significant moisture or viscosity changes were observed in RS, suggesting that RS is better at water retention during processing.

All treatments reduced the TA and $\mathrm{pH}$ in all sugarcane variants. This reduction might be beneficial in terms of browning inhibition, as enzymatic browning by $\mathrm{PPO}$ works best at $\mathrm{pH} 7.2$ (Araújo Gomes et al., 2001). Apart from the conversion of sugar to acid, the reduction can also be contributed to protein denaturation and protons released during certain processing conditions (Rustom et al., 1996). Based on the evidence presented, RS may be a suitable candidate for commercialisation as many of the physicochemical qualities are preserved during the processing of the juice.

In addition to ${ }^{\circ}$ Brix determination, HPLC analysis on the different types of sugar (glucose, fructose and sucrose) in both variants was also conducted (Figure 1). In line with the ${ }^{\circ}$ Brix result, all types of sugars in RS were significantly higher than YS, therefore it is the sweeter version of sugarcane juice. Sucrose was the dominant sugar in both sugarcane variants whilst fructose was the lowest. All treatments at all times did not affect the sugar levels in the juices, except for sucrose level in certain treatments in RS. Both treatments (heat and sonication) at 15 minutes lead to significantly lower sucrose, with larger declines detected in RS. This observation indicated that RS is prone to processing changes, although it is not necessarily a bad outcome as it might be beneficial for health.

Minimal change colour change during processing is a very important trait for the food industry (Bomdespacho et al., 2018; Thakur et al., 1996). Colour changes of the sugarcane juice as a result of heat treatment for 5 and 15 minutes and ultrasonic

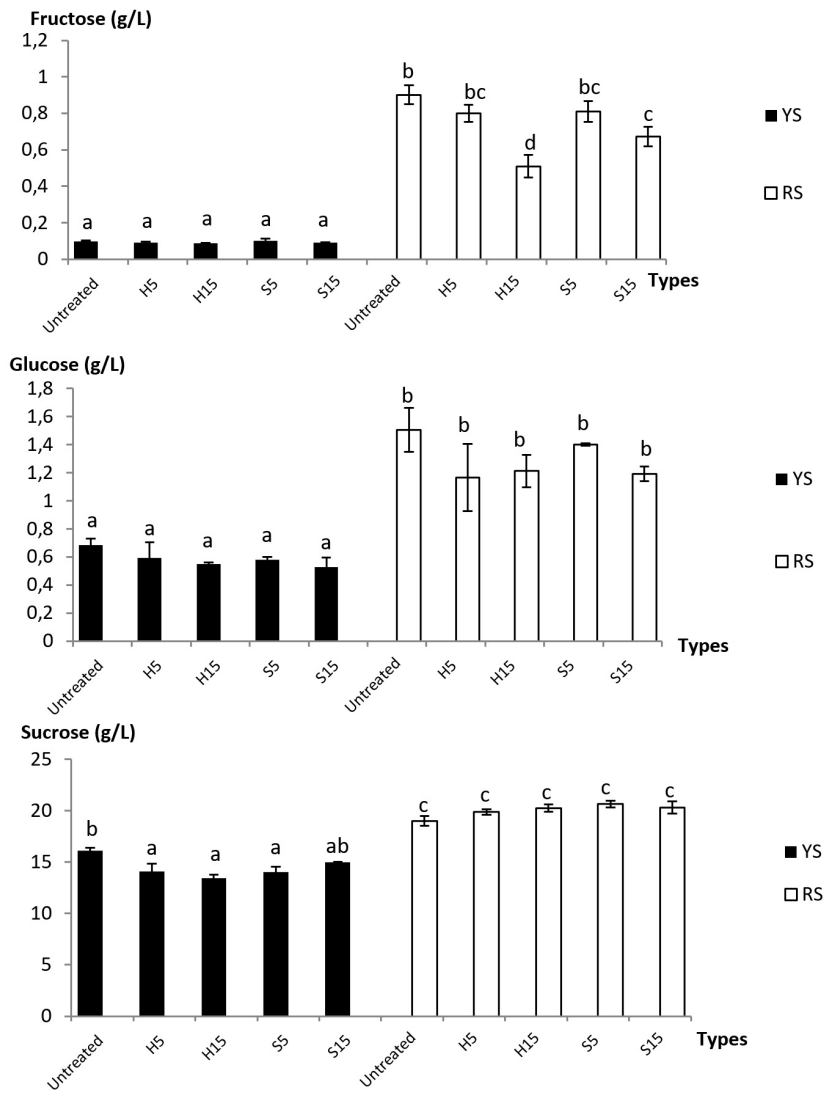

Figure 1. The fructose, glucose and sucrose content in untreated, heat-treated and ultrasound-treated YS and RS juice. H5 - heat $5 \mathrm{~min}$; H15 - heat $15 \mathrm{~min}$; S5 - sonication $5 \mathrm{~min}$; S15 - sonication $15 \mathrm{~min}$. Means with different a subscript letter indicate the samples are significantly different $(\mathrm{p}<0.05)$.

treatment for $40^{\circ} \mathrm{C}$ and $60^{\circ} \mathrm{C}$ is displayed in Table 2. Lightness $\left(\mathrm{L}^{*}\right)$, redness $\left(\mathrm{a}^{*}\right)$ and yellowness $\left(\mathrm{b}^{*}\right)$ were significantly different $(\mathrm{p}<0.05)$ between sugarcane variants. Both heat and sonication treatments on RS showed a significant decrease in lightness and increase in redness, which translates to darker juice. This darker appearance is likely caused by the accelerated Maillard reaction effect (Guiseppi-Elie et al., 2009) or the effect of cavitation (Tiwari et al., 2008), while the colour changes under 
Table 2. Effects of heat treatment and sonication on the colour of the different sugarcane juice variants.

\begin{tabular}{|c|c|c|c|c|c|c|}
\hline \multirow{2}{*}{ Treatment } & \multirow{2}{*}{ Sample } & \multirow{2}{*}{ Time (min) } & \multirow{2}{*}{$\mathrm{T}\left({ }^{\circ} \mathrm{C}\right)$} & \multicolumn{3}{|c|}{ Colour values } \\
\hline & & & & $\mathrm{L}^{*}$ & $a^{*}$ & $b^{*}$ \\
\hline Untreated & YS & - & - & $76.35 \pm 0.74^{\mathrm{aA}}$ & $-0.48 \pm 0.03^{\mathrm{aA}}$ & $22.42 \pm 0.38^{\mathrm{aA}}$ \\
\hline \multirow[t]{2}{*}{ Heat } & & 5 & 90 & $76.09 \pm 0.43^{\mathrm{aA}}$ & $-0.35 \pm 0.09^{\mathrm{aA}}$ & $20.47 \pm 0.27^{\mathrm{aB}}$ \\
\hline & & 15 & 90 & $76.76 \pm 1.28^{\mathrm{aA}}$ & $0.17 \pm 0.19^{\mathrm{aB}}$ & $21.10 \pm 0.31^{\mathrm{ab}}$ \\
\hline \multirow[t]{2}{*}{ Sonication } & & 5 & 40 & $78.57 \pm 0.08^{\mathrm{aB}}$ & $-0.73 \pm 0.05^{\mathrm{aA}}$ & $20.64 \pm 0.17^{\mathrm{aB}}$ \\
\hline & & 15 & 40 & $76.09 \pm 0.51^{\mathrm{aA}}$ & $0.02 \pm 0.10^{\mathrm{aB}}$ & $21.94 \pm 0.13^{\mathrm{aA}}$ \\
\hline Untreated & RS & - & - & $60.99 \pm 0.11^{\mathrm{bC}}$ & $2.78 \pm 0.03^{\mathrm{aC}}$ & $38.75 \pm 0.16^{\mathrm{bC}}$ \\
\hline \multirow[t]{2}{*}{ Heat } & & 5 & 90 & $56.36 \pm 0.07^{\mathrm{bD}}$ & $4.37 \pm 0.03^{\mathrm{aDE}}$ & $35.10 \pm 0.09^{b D}$ \\
\hline & & 15 & 90 & $55.88 \pm 1.14^{\mathrm{bD}}$ & $4.35 \pm 0.59^{\mathrm{aDE}}$ & $36.13 \pm 0.40^{\mathrm{bE}}$ \\
\hline \multirow[t]{2}{*}{ Sonication } & & 5 & 40 & $54.98 \pm 1.13^{\mathrm{bD}}$ & $4.20 \pm 0.47^{\mathrm{aD}}$ & $37.74 \pm 0.36^{\mathrm{bF}}$ \\
\hline & & 15 & 40 & $52.06 \pm 0.67^{\mathrm{bE}}$ & $4.96 \pm 0.21^{\mathrm{aE}}$ & $36.18 \pm 0.54^{\mathrm{bE}}$ \\
\hline
\end{tabular}

Data given as mean \pm standard deviation where $(n=3)$. Values with a small letter represent significant difference between sugarcane variants while a capital letter represents significant difference between sugarcane sample and treatment in the particular column. $\mathrm{L}^{*}-$ lightness; $\mathrm{a}^{*}-$ redness; $b^{*}$ - yellowness.

high temperature is attributed to the deterioration of chlorophyll (Huang et al., 2015). In contrast, only minimal changes were detected in YS. These results suggested that although RS retains most of its physicochemical properties, it may produce a less favourable appearance after processing. The use of ultrasound treatment coupled with mild heat can be applied to minimize the undesirable effects of chemical and physical changes of juice (Bhat, 2016).

As previously described, sugarcane juice may contain many bioactive compounds, such as phenolic-based chemical and antioxidants. Based on Figure 2, both sugarcane variants demonstrated strong DPPH free radical scavenging activity, at $37.34 \%$ and $33.49 \%$ for RS and YS, respectively. While containing less sugar, YS displayed superior antioxidant capacity and TPC, as evidenced by a significantly higher TPC of almost $31.15 \%$ than RS. Nevertheless, the treatments were shown to be detrimental to the antioxidant and TPC values in both sugarcane variants. In general, the increased duration of treatments were shown to affect the DPPH activity significantly. RS was shown to be more prone to adverse effect of the treatments, as its reduction percentage was steeper than YS. For example, a 5 minute heat treatment caused up to $33.08 \%$ reduction in DPPH activity in RS, but only $23.30 \%$ reduction was observed in YS. Similarly, heat treatment in TPC affected RS the most, with a maximum reduction of TPC at $38.45 \%$, compared to $23.71 \%$ for YS. However, only sonication at 15 minutes affected YS the most, with a decline of up to $52.87 \%$. The effect of heat on the antioxidant contents is well described in the literature (Chipurura et al., 2010; Sultana et al., 2008), while typically, sonication can preserve or improve the amount of antioxidants in the food system, as reported by (Zou \& Hou, 2017) and (Alighourchi et al., 2013). This demonstrates that the effect of sonication on the antioxidant activity may vary in different food systems.

\subsection{Effect of heat and sonication the growth of microorganisms}

Although conventional heat treatment is typically effective in reducing microbial growth on food products, there are concerns regarding the deterioration of nutritional qualities. Therefore, minimal processing such as ultrasound technology may be

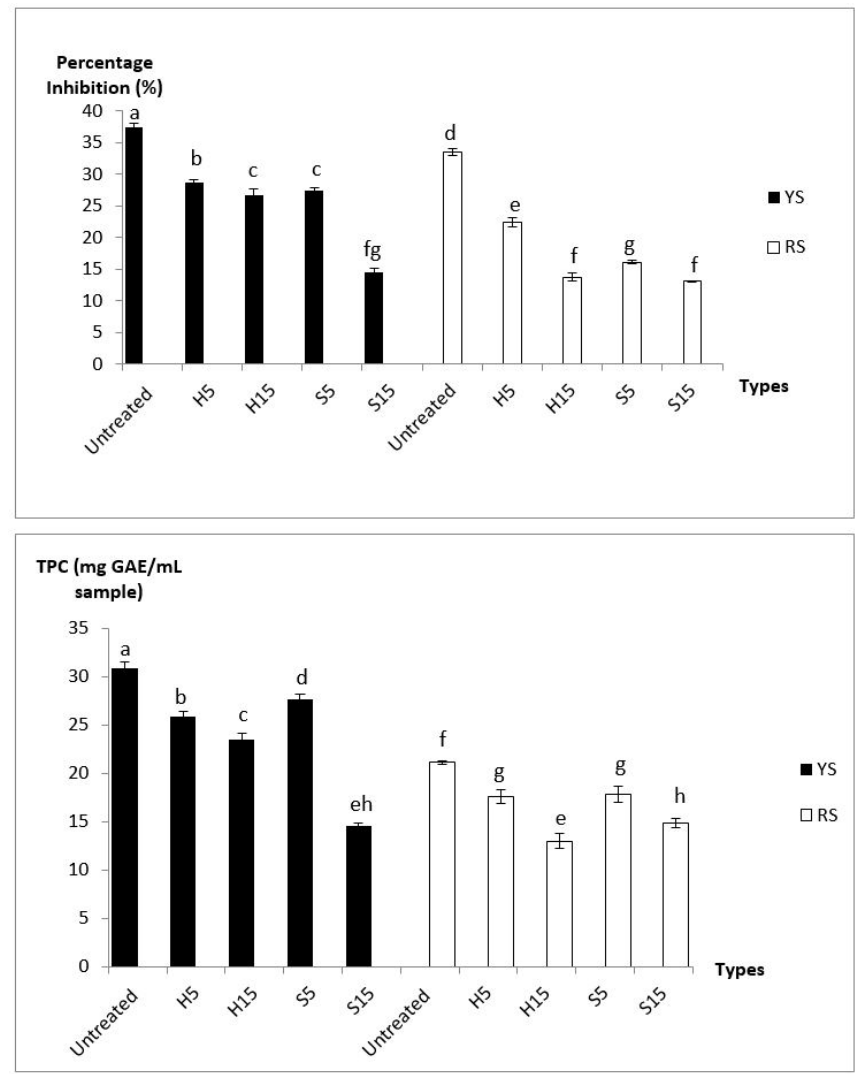

Figure 2. The DPPH and TPC in untreated, heat-treated and ultrasound-treated YS and RS juice. H5 - heat 5 min; H15 - heat 15 min; S5 - sonication 5 min; S15 - sonication 15 min. Means with a different subscript letter indicate that the samples are significantly different $(\mathrm{p}<0.05)$.

employed as an alternative to minimize the quality deterioration but at the same time, is still able to reduce microbial content in food products (Chen, 2017; Piyasena et al., 2003; Yikmiş, 2019). Sonication is considered to be safe, non-toxic and environmentally friendly (Kentish \& Ashokkumar, 2011).

The results for the effectiveness of heat and sonication treatments in reducing the number of foodborne pathogens in 
Table 3. Effects of heat treatment and sonication on total plate count of sugarcane juice.

\begin{tabular}{|c|c|c|c|c|}
\hline \multirow{2}{*}{ Treatment } & \multirow{2}{*}{ Time (min) } & \multirow{2}{*}{ Temperature $\left({ }^{\circ} \mathrm{C}\right)$} & \multicolumn{2}{|c|}{ Log of colony forming unit/10ml } \\
\hline & & & YS & RS \\
\hline Untreated & - & - & $6.03 \pm 0.07^{\mathrm{aA}}$ & $5.88 \pm 0.03^{\mathrm{aD}}$ \\
\hline \multirow[t]{2}{*}{ Heat } & 5 & 90 & $5.37 \pm 0.10^{\mathrm{aB}}$ & $5.14 \pm 0.09^{\mathrm{aF}}$ \\
\hline & 15 & 90 & $4.75 \pm 0.21^{\mathrm{aC}}$ & $4.75 \pm 0.21^{\mathrm{aF}}$ \\
\hline \multirow[t]{2}{*}{ Sonication } & 30 & 40 & Nil & Nil \\
\hline & 30 & 40 & Nil & Nil \\
\hline
\end{tabular}

Data given as mean \pm standard deviation where $(n=4)$. Values with a small letter represent significant difference between sugarcane variants while a capital letter represents significant difference between sugarcane sample and treatment.

sugarcane juice are displayed in Table 3. Control experiments (untreated) showed no significant difference ( $\mathrm{p}>0.05$ ) of log colony forming unit (CFU) between different sugarcane variants which indicates that both are similarly prone to the contamination of microorganisms. All heat treatments showed significantly lower CFU compared to controls at the end of the experiment, which confirms that heat is an effective way of controlling microbial growth. Surprisingly, sonication was shown to be more effective in this study, as all sonication treatments reduced the microbial count to zero. It is likely that differences in the food matrix of the sugarcane juice contributed to the improved microbial count, and was further assisted by mild heat treatment at $40^{\circ} \mathrm{C}$. This particular temperature was chosen based on its minimal role in degradation of nutritional content, but is optimal at reducing microbial growth (Hajar et al., 2018). The effectiveness of sonication in controlling microbial growth has also been previously reported (Bhat et al., 2011; Carrillo-Lopez et al., 2019; Yikmiş, 2019). Hayer (2010) suggested that sonication treatment might disperse microorganism clumps, disrupt cells and modify its cellular activities, leading to the inhibition of microbial growth (Hayer, 2010).

\section{Conclusion}

The processing of juice such as sugarcane often requires a delicate balance between preservation of the qualities of the juice and improvements in microbial growth control. RS was shown to be more resistant to the physicochemical changes imparted by both heat and sonication treatment, but lower in nutritional values. Sonication was shown to be better at improving microbial growth control, which is advantageous due to its minimal processing properties.

\section{References}

Abbasi, F., Samadi, F., Jafari, S. M., Ramezanpour, S., \& Shams Shargh, M. (2019). Ultrasound-assisted preparation of flaxseed oil nanoemulsions coated with alginate-whey protein for targeted delivery of omega-3 fatty acids into the lower sections of gastrointestinal tract to enrich broiler meat. Ultrasonics Sonochemistry, 50, 208-217. http://dx.doi. org/10.1016/j.ultsonch.2018.09.014. PMid:30249371.

Alighourchi, H. R., Barzegar, M., Sahari, M. A., \& Abbasi, S. (2013). Effect of sonication on anthocyanins, total phenolic content, and antioxidant capacity of pomegranate juices. International Food Research Journal, 20(4), 1703-1709.

Araújo Gomes, M. R., Goreti de Almeida Oliveira, M., Estevam, G., Carneiro, S., Gonçalves de Barros, E., \& Moreira, M. A. (2001).
Physical chemical properties of poliphenoloxidase from beans (Phaseolus vulgaris L.). Food Science and Technology, 21(1), 69-72.

Balthazar, C. F., Santillo, A., Guimarães, J. T., Bevilacqua, A., Corbo, M. R., Caroprese, M., Marino, R., Esmerino, E. A., Silva, M. C., Raices, R. S. L., Freitas, M. Q., Cruz, A. C., \& Albenzio, M. (2019). Ultrasound processing of fresh and frozen semi-skimmed sheep milk and its effects on microbiological and physical-chemical quality. Ultrasonics Sonochemistry, 51, 241-248. http://dx.doi.org/10.1016/j. ultsonch.2018.10.017. PMid:30377079.

Bhat, R. (2016). Impact of ultraviolet radiation treatments on the quality of freshly prepared tomato (Solanum lycopersicum) juice. Food Chemistry, 213, 635-640. http://dx.doi.org/10.1016/j. foodchem.2016.06.096. PMid:27451228.

Bhat, R., Kamaruddin, N. S. B. C., Min-Tze, L., \& Karim, A. A. (2011). Sonication improves kasturi lime (Citrus microcarpa) juice quality. Ultrasonics Sonochemistry, 18(6), 1295-1300. http://dx.doi. org/10.1016/j.ultsonch.2011.04.002. PMid:21550834.

Bhavya, M. L., \& Hebbar, H. U. (2019). Sono-photodynamic inactivation of Escherichia coli and Staphylococcus aureus in orange juice. Ultrasonics Sonochemistry, 57, 108-115. http://dx.doi.org/10.1016/j. ultsonch.2019.05.002. PMid:31208605.

Bomdespacho, L. Q., Silva, B. T. R., Lapa-Guimaraes, J., Ditchfield, C., \& Petrus, R. R. (2018). Cultivar affects the color change kinetics of sugarcane juice. Food Science and Technology, 38(Suppl. 1), 96-102. http://dx.doi.org/10.1590/fst.15017.

Carrillo-Lopez, L. M., Luna-Rodriguez, L., Alarcon-Rojo, A. D., \& Huerta-Jimenez, M. (2019). High intensity ultrasound homogenizes and improves quality of beef longissimus dorsi. Food Science and Technology, 39(Suppl. 1), 332-340. http://dx.doi.org/10.1590/fst.05218.

Chauhan, O. P., Singh, D., Tyagi, S. M., \& Balyan, D. K. (2002). Studies on preservation of sugarcane juice. International Journal of Food Properties, 5(1), 217-229. http://dx.doi.org/10.1081/JFP-120015603.

Chen, Z. (2017). Microbial inactivation in foods by ultrasound. Journal of Food: Microbiology. Safety \& Hygiene, 2(1), 102.

Chipurura, B., Muchuweti, M., \& Manditsera, F. (2010). Effects of thermal treatment on the phenolic content and antioxidant activity of some vegetables. Asian Journal of Clinical Nutrition, 2(3), 93-100. http://dx.doi.org/10.3923/ajcn.2010.93.100.

El-Abasy, M., Motobu, M., Shimura, K., Na, K.-J., Kang, C.-B., Koge, K., Onodera, T., \& Hirota, Y. (2002). Immunostimulating and growth-promoting effects of Sugar Cane Extract (SCE) in chickens. The Journal of Veterinary Medical Science, 64(11), 1061-1063. http:// dx.doi.org/10.1292/jvms.64.1061. PMid:12499696.

Fernández-Barbero, G., Pinedo, C., Espada-Bellido, E., Ferreiro-González, M., Carrera, C., Palma, M., \& García-Barroso, C. (2019, ahead of print). Optimization of ultrasound-assisted extraction of bioactive 
compounds from jabuticaba (Myrciaria cauliflora) fruit through a Box-Behnken experimental design. Food Science and Technology.

Gizachew, G., Gezahegn, G., \& Seifu, F. (2016). Chemical composition of mango (Mangifera Indica $L$ ) fruit as influence by postharvest treatments in Arba Minch, Southern Ethiopia. Journal of Environmental Science Technology and Food Technology, 10(11), 70-77.

Guimarães, J. T., Balthazar, C. F., Scudino, H., Pimentel, T. C., Esmerino, E. A., Ashokkumar, M., Freitas, M. Q., \& Cruz, A. G. (2019a). Highintensity ultrasound: A novel technology for the development of probiotic and prebiotic dairy products. Ultrasonics Sonochemistry, 57, 12-21. http://dx.doi.org/10.1016/j.ultsonch.2019.05.004. PMid:31208607.

Guimarães, J. T., Silva, E. K., Ranadheera, C. S., Moraes, J., Raices, R. S. L., Silva, M. C., Ferreira, M. S., Freitas, M. Q., Meireles, M. A. A., \& Cruz, A. G. (2019b). Effect of high-intensity ultrasound on the nutritional profile and volatile compounds of a prebiotic soursop whey beverage. Ultrasonics Sonochemistry, 55, 157-164. http://dx.doi. org/10.1016/j.ultsonch.2019.02.025. PMid:30853535.

Guiseppi-Elie, A., Choi, S.-H., \& Geckeler, K. (2009). Ultrasonic processing of enzymes: Effect on enzymatic activity of glucose oxidase. Journal of Molecular Catalysis. B, Enzymatic, 58(1-4), 118-123. http://dx.doi. org/10.1016/j.molcatb.2008.12.005.

Hajar, A., Raudah, S., \& Muhamad Hafiz, A. R. (2018). The effect of heat treatment and sonication on physicochemical and colour attributes of yellow sugarcane juice. Malaysian Applied Biology, 47(5), 129-134.

Hayer, K. (2010). The effect of ultrasound exposure on the transformation efficiency of Escherichia coli HB101. Bioscience Horizons, 3(2), 141147. http://dx.doi.org/10.1093/biohorizons/hzq018.

Horwitz, W., \& Latimer, G. W. (2005). Official methods of analysis. association of official analytical chemists (18th ed., Vol. 18). Maryland: AOAC International.

Huang, H. W., Chang, Y. H., \& Wang, C. Y. (2015). High pressure pasteurization of sugarcane juice: evaluation of microbiological shelf life and quality evolution during refrigerated storage. Food and Bioprocess Technology, 8(12), 2483-2494. http://dx.doi.org/10.1007/ s11947-015-1600-2.

Juszczak, L., Witczak, M., Fortuna, T., \& Solarz, B. (2010). Effect of temperature and soluble solids content on the viscosity of beetroot (Beta vulgaris) juice concentrate. International Journal of Food Properties, 13(6), 1364-1372. http://dx.doi.org/10.1080/10942912 .2010 .490896 .

Kadam, U. S., Ghosh, S. B., De, S., Suprasanna, P., Devasagayam, T. P. A., \& Bapat, V. A. (2008). Antioxidant activity in sugarcane juice and its protective role against radiation induced DNA damage. Food Chemistry, 106(3), 1154-1160. http://dx.doi.org/10.1016/j. foodchem.2007.07.066.

Kentish, S., \& Ashokkumar, M. (2011). The physical and chemical effects of ultrasound. In H. Feng, G. Barbosa-Canovas \& J. Weiss. Ultrasound technologies for food and Bioprocessing (Food Engineering Series). New York: Springer.

Khare, A., Lal, A. B., Singh, A., \& Singh, A. P. (2012). Shelflife enhancement of sugarcane juice. Croatian Journal of Food Techology, Biotechnology and Nutrition, 7(3-4), 179-183.
Krishnakumar, T. (2012). Biochemical changes of sugarcane juice during storage in different packaging materials. International Journal of Processing and Post Harvesting Technology, 3, 256-259.

Mohd Khairi, M. T., Ibrahim, S., Md Yunus, M. A., \& Faramarzi, M. (2018). Ultrasonic tomography for detecting foreign objects in refrigerated milk cartons. International Journal of Dairy Technology, 71(4), 1005-1011. http://dx.doi.org/10.1111/1471-0307.12534.

Nurul, S. R., Patimah, I., Asmah, R. (2012). Evaluation of antioxidant properties in fresh and pickled papaya. International Food Research Journal. 19(3), 1117-1124.

Piyasena, P., Mohareb, E., \& McKellar, R. C. (2003). Inactivation of microbes using ultrasound: A review. International Journal of Food Microbiology, 87(3), 207-216. http://dx.doi.org/10.1016/S01681605(03)00075-8. PMid:14527793.

Ranganna, S. (1979). Manual of analysis of fruit and vegetable products. New York: Tata McGraw-Hill.

Rustom, I. Y. S., López-Leiva, M. H., \& Nair, B. M. (1996). Nutritional, sensory and physicochemical properties of peanut beverage sterilized under two different UHT conditions. Food Chemistry, 56(1), 45-53. http://dx.doi.org/10.1016/0308-8146(95)00153-0.

Solomon, S., \& Li, Y.-R. (2016). Editorial: the sugar industry of Asian Region. Sugar Tech, 18(6), 557-558. http://dx.doi.org/10.1007/ s12355-016-0500-8.

Soltani, R., Shahvar, A., Dinari, M., \& Saraji, M. (2018). Environmentallyfriendly and ultrasonic-assisted preparation of two-dimensional ultrathin Ni/Co-NO3 layered double hydroxide nanosheet for micro solid-phase extraction of phenolic acids from fruit juices. Ultrasonics Sonochemistry, 40(Pt A), 395-401. http://dx.doi.org/10.1016/j. ultsonch.2017.07.031. PMid:28946438.

Sultana, B., Anwar, F., \& Iqbal, S. (2008). Effect of different cooking methods on the antioxidant activity of some vegetables from Pakistan. International Journal of Food Science \& Technology, 43(3), 560-567. http://dx.doi.org/10.1111/j.1365-2621.2006.01504.x.

Tandon, K., Worobo, R. W., Churey, J. J., \& Padilla-Zakour, O. I. (2003). Storage quality of pasteurized and UV treated apple cider. Journal of Food Processing and Preservation, 27(1), 21-35. http://dx.doi. org/10.1111/j.1745-4549.2003.tb00498.x.

Thakur, B. R., Singh, R. K., \& Nelson, P. E. (1996). Quality attributes of processed tomato products: A review. Food Reviews International, 12(3), 375-401. http://dx.doi.org/10.1080/87559129609541085.

Tiwari, B. K., Muthukumarappan, K., O’Donnell, C. P., \& Cullen, P. J. (2008). Colour degradation and quality parameters of sonicated orange juice using response surface methodology. LebensmittelWissenschaft + Technologie, 41(10), 1876-1883. http://dx.doi. org/10.1016/j.lwt.2007.11.016.

Yikmiş, S., (2019, ahead of print). Effect of ultrasound on different quality parameters of functional sirkencubin syrup. Food Science and Technology.

Zou, Y., \& Hou, X. (2017). Sonication enhances quality and antioxidant activity of blueberry juice. Food Science and Technology, 37(4), 599603. http://dx.doi.org/10.1590/1678-457x.27816. 